\title{
DETERMINAN NON PERFORMING FINANCING (NPF) \\ PADA SEGMEN BUSINESS BANKING (STUDI KASUS DI PT BANK SYARIAH X)
}

\author{
R. Bagus Sugiharto ${ }^{1}$, Nunung Nuryartoro ${ }^{2}$, Jaenal Effendi ${ }^{3}$ \\ ${ }^{1}$ Sekolah Bisnis Institut Pertanian Bogor \\ email: rbsugiharto@gmail.com \\ ${ }^{2}$ Program Studi Ekonomi Indonesia Fakultas Ekonomi dan Manajemen Institut Pertanian Bogor \\ email:nnuryar@gmail.com
${ }^{3}$ Program Studi IImu Ekonomi Syariah Fakultas Ekonomi dan Manajemen Institut Pertanian Bogor email: jaeefendi@gmail.com

Article History :
Recieved 4 Januari 2019
Recieved in revished form
17 Januarir 2019
Acepted 23 Januari 2019
Available offline 29 Januari 2019
Available online 30 Januari 2019

Language Transcript : Indonesia (id)

Key Words :

Non Performing Financing (NPF)

Error Corrective Model (ECM) BOPO

$C A R$

FDR
Abstrak - Penelitian ini bertujuan untuk menganalisis Non Performing Financing (NPF) segmen bisnis banking di PT Bank Syariah $X$. Variabel independen yang digunakan dalam penelitian ini adalah adalah rasio rentabilitas (BOPO), rasio permodalan $(C A R)$, rasio likuiditas (FDR), rasio rentabilitas (NIM), BI rate dan Inflasi. Populasi dalam penelitian ini adalah data Non Performing Financing pada segmen bisnis banking di PT. Bank Syariah X periode Januari 2012 sampai dengan Desember 2016 berupa data bulanan. Teknik pengambilan sampel yang digunakan adalah purposive sampling dan metode analisis data yang digunakan dalam penelitian ini menggunakan analisis Error Corrective Model (ECM). Hasil penelitian ini menunjukkan bahwa dalam jangka panjang $B O P O, C A R, F D R$, NMR dan BI rate mempunyai pengaruh positif terhadap Non Performing Financing segmen bisnis banking; sedangkan Inflasi tidak berpengaruh terhadap Non Performing Financing segmen bisnis banking. Dalam jangka pendek BOPO mempunyai pengaruh positif terhadap Non Performing Financing segmen bisnis banking; sedangkan CAR, $F D R, N M R, B I$ rate dan inflasi tidak mempunyai pengaruh terhadap Non Performing Financing segmen Bisnis Banking.

\section{PENDAHULUAN}

Ditengah persaingan dunia perbankan yang semakin ketat dan kondisi perekonomian global yang cenderung menurun yang diakibatkan oleh pemulihan ekonomi global yang cenderung lambat dan tidak merata, hal ini berdampak pada turunnya daya beli masyarakat khususnya menengah ke bawah. Dengan kondisi ini bank perlu berhati-hati serta lebih selektif dalam melakukan penyaluran pembiayaan mengingat tingginya Non Performance Financing (NPF) menunjukkan potensi tidak tertagih semakin besar. Semakin tinggi tingkat Non Performance Financing (NPF) yang dimiliki, maka semakin tinggi pula premi resiko atau risk premium yang harus dibentuk. Kinerja bank yang kurang hatihati serta serta tidak efisien dalam menyalurkan pembiayaan ditunjukkan dengan tingkat Non Performing Financing (NPF) yang tinggi. Sutojo (2000) menyatakan "salah satu 
implementasi dari budaya penyaluran kredit yang sehat adalah adanya penerapan prinsip kehati-hatian (prudent approach). Dalam melakukan penyaluran pembiayaan, bank tidak hanya memikirkan jumlah bagi hasil maupun pendapatan lainnya yang akan diperoleh, namun juga perlu membandingkan jumlah pendapatan dengan resiko kredit yang akan muncul.

Berdasarkan laporan perekonomian Indonesia tahun 2016 disampaikan bahwa telah terjadi perlambatan pertumbuhan kredit pada tahun 2016 sebesar 7,9\% dari posisi tahun sebelumnya yang mencapai $10.5 \%$. Hal ini disebabkan adanya proses konsolidasi yang terjadi pada korporasi. Perlambatan pertumbuhan kredit ini terjadi baik dari sisi permintaan maupun penawaran. Dari sisi permintaan terjadi karena proses konsolidasi korporasi dan cenderung menunda melakukan proses ekspansi. Sedangkan dari sisi penawaran terjadi karena perbankan lebih berhati-hati dalam melakukan penyaluran pembiayaan yang disebabkan meningkatnya persepsi resiko kredit pada tahun 2016. Seiring dengan perlambatan penyaluran pembiayaan, sepanjang tahun 2016 resiko kredit perbankan (NPF) cenderung mengalami peningkatan meskipun masih berada dibawah batas aman 5\%. Rasio NPL gross perbankan pada tahun 2016 mengalami peningkatan menjadi $2.9 \%$ dari 2.5\% pada tahun sebelumnya. Jika dibandingkan dengan negara-negara peer group, peningkatan NPF yang terjadi pada industri perbankan di Indonesia relatif sejalan dengan tren peningkatan NPF yang terjadi di kawasan ASEAN maupun peer countries yang umumnya terdampak oleh perlambatan ekonomi global.

Cadangan kerugian yang dibentuk oleh bank merupakan salah satu komponen penentuan laba perusahaan. Apabila tingkat perolehan laba perusahaan semakin tinggi, maka bank akan lebih mudah menyalurkan pembiayaan dengan tingkat bagi hasil yang rendah. Semakin rendah tingkat bagi hasil atas penyaluran pembiayaan yang diberikan, maka semakin tinggi pula minat masyarakat untuk mengambil atau memanfaatkan pembiayaan tersebut.

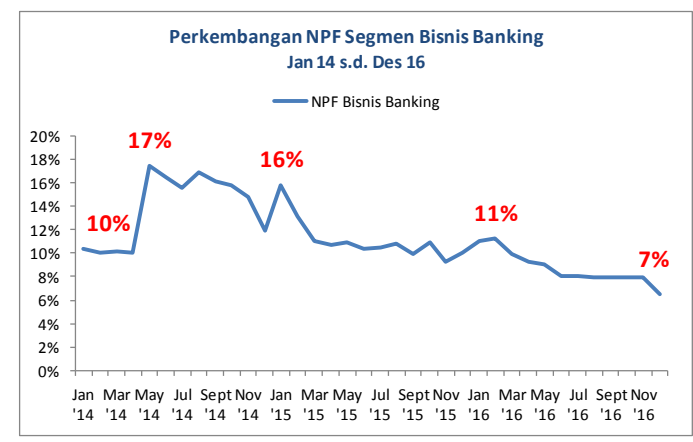

Gambar 1

Tren Pembiayaan
Bermasalah Segmen Bisnis
Banking
Sumber : Data Internal PT
Bank Syariah X (2016)

Berdasarkan data kinerja PT Bank Syariah $\mathrm{X}$, posisi NPF pembiayaan segmen Bisnis Banking secara relatif sejak Januari 2014 hingga Desember 2016 selalu berada pada posisi lebih dari $5 \%$. Posisi tertinggi NPF segmen Bisnis Banking terjadi pada bulan Juni 2014 yaitu sebesar $16,50 \%$, sementara posisi terendah terjadi pada bulan Juni 2012 sebesar 4,90\%. Kondisi ini menunjukkan kinerja yang kurang baik yang disebabkan tidak sesuai dengan Peraturan Bank Indonesia dimana perbankan wajib menjaga NPF berada di bawah 5\% agar dikatakan sebagai bank yang sehat.

\section{METODOLOGI}

Metode analisis yang digunakan dalam penelitian ini menggunakan analisis EngelGrangger untuk Non Performing Financing (NPF) segmen bisnis banking jangka panjang dan model Error Correction Mechanism (ECM) untuk Non Performing Financing (NPF) segmen Bisnis Banking jangka pendek. Data yang digunakan adalah Non Performing Financing (NPF), BO/PO, Capital Adequacy Ratio (CAR), Financing to Deposit Ratio (FDR), Nett Margin 
Revenue (NMR), BI rate dan Inflasi selama periode Januari 2012 sampai Desember 2016.

Sebelum menggunakan metode ECM, konsep yang banyak digunakan untuk menguji kestasioneran data runtun waktu adalah uji akar unit (unit root test) atau dikenal juga dengan uji Dickey Fuller (ADF). Jika semua variabel yang digunakan lolos dari unit root test, maka pada tahap selanjutnya dilakukan uji kointegrasi (cointegration test) untuk mengetahui keseimbangan atau kestabilan jangka panjang di dalam variabel-variabel yang dilakukan pengamatan dan arah pengaruh yang diberikan oleh variabel-variabel tersebut terhadap Non Performing Financing (NPF).

Salah satu asumsi penting pada saat melakukan pendugaan parameter model regresi dengan metode kuadrat terkecil (least square) yaitu error (residual) yang homoskedastis, yang berarti ragam peubah tak bebas (Yt) harus konstan $\left(\operatorname{Var}(\mathrm{Yt})=\sigma^{2}\right)$. Asumsi lainnya adalah tidak ada korelasi antar-error, yang juga mengandung pengertian tidak ada korelasi diantara peubah Yt dengan Yt-1 atau Yt yang lain (tidak ada autokorelasi).

\section{HASIL DAN PEMBAHASAN}

\subsection{Hasil Regresi dan Analisis ECM}

Persamaan regresi bertujuan menentukan seberapa besar variabel BOPO, CAR, FDR, NMR, BI Rate dan Inflasi berpengaruh terhadap NPF. Berdasarkan hasil pengolahan data diperoleh persamaan jangka panjang sbb:

$\mathrm{NPF}_{\mathrm{t}}=-0.6666+2.2750 \mathrm{BI}$ _Rate + $0.5051 \mathrm{BOPO}+1.6528 \mathrm{CAR}-0.0956 \mathrm{FDR}-$ 0.2198 INFLASI - $0.4208 \mathrm{NMR}$

Berdasarkan persamaan tersebut di atas, secara statistik terdapat variabel yang tidak berpengaruh secara signifikan terhadap Non
Performing Financing (NPF) segmen Bisnis Banking. Variabel yang tidak berpengaruh secara signifikan dalam jangka panjang adalah variabel inflasi dengan nilai probabilitas sebesar 0.2494 (probabilitasnya lebih dari 0.05). Sementara variabel lainnya memiliki pengaruh yang signifikan karena probabilitasnya berada dibawah 0.05 . Nilai $R$-square yang diperoleh berdasarkan persamaan regresi adalah sebesar $73.11 \%$ yang berarti bahwa sebesar $73.11 \%$ dari variasi dalam NPF dapat dijelaskan oleh variabel BOPO, CAR, FDR, NMR, BI Rate dan Inflasi. Sisanya sebesar $26.89 \%$ dapat dijelaskan oleh variabel mempenaruhi diluar model yang digunakan.

Sedangkan persamaan jangka pendek yang diperoleh berdasarkan perhitungan di atas adalah sbb:

$\Delta \mathrm{NPF}_{\mathrm{t}}=-1.35+0.2898 \mathrm{BI} \_$Rate $0.3721 \mathrm{BOPO}-0.0785 \mathrm{CAR}-0.0111 \mathrm{FDR}$ 0.2272 INFLASI - $0.1238 \mathrm{NMR} \quad$ $0.2567 \mathrm{ECT}$

Hasil persamaan ini memberikan informasi bahwa dalam jangka pendek, variabel BI rate, BOPO, CAR, FDR, Inflasi dan NMR tidak memiliki pengaruh yang signifikan terhadap NPF segmen Bisnis Banking.

\subsection{Jangka Pendek dan Jangka Panjang}

Nilai t-statistik variabel BOPO sebesar 4.6604 dengan probabilitas sebesar 0.0000 dan koefisien jangka pendek sebesar 0.3721 . Hal ini mengandung pengertian bahwa variabel BOPO berpengaruh signifikan pada tingkat kepercayaan $\alpha(5 \%)$ dan membawa implikasi bahwa terdapat hubungan jangka pendek antara BOPO terhadap NPF segmen Bisnis Banking. Sementara nilai t-statistik variabel BOPO jangka panjang sebesar 4.5697 dengan probabilitas sebesar 0.0000 dan koefisien jangka panjang sebesar 0.5051. Hal ini mengandung pengertian bahwa variabel BOPO berpengaruh signifikan pada tingkat kepercayaan $\alpha(5 \%)$ dan membawa implikasi bahwa terdapat hubungan jangka 
panjang positif antara BOPO terhadap NPF segmen Bisnis Banking, dimana apabila BOPO mengalami peningkatan satu persen maka akan meningkatkan NPF segmen Bisnis Banking sebesar 0.5051, atau sebaliknya apabila BOPO mengalami penurunan sebesar satu persen maka akan menurunkan NPF segmen Bisnis Banking sebesar 0.5051. Riyadi (2006) menjelaskan bahwa BOPO adalah perbandingan antara biaya operasional terhadap terhadap pendapatan operasional. Peningkatan yang terjadi pada rasio BOPO menunjukkan bahwa biaya operasional yang dikeluarkan tidak digunakan secara efisien. Dengan demikian dapat disampaikan bahwa tinggi rendahnya pada rasio BOPO suatu bank akan berpengaruh terhadap pembiayaan bermasalah (NPF). Adanya efisiensi, khusunya efisiensi biaya pada lembaga keuangan maka tingkat keuntungan yang diperoleh akan optimal, peningkatan jumlah dana yang disalurkan, biaya menjadi lebih kompetitif, adanya peningkatan layanan kepada nasabah, serta keamanan dan kesehatan bank akan meningkat. Efisiensi yang baik akan berdampak pada semakin kecil rasio $\mathrm{BOPO}$, sehingga kondisi pembiayaan bermasalah juga akan semakin kecil.

Nilai t-statistik variabel CAR jangka panjang sebesar 5.3207 dengan probabilitas sebesar 0.0000 dan koefisien jangka panjang sebesar 1.6528. Hal ini mengandung pengertian bahwa variabel CAR berpengaruh signifikan pada tingkat kepercayaan $\alpha(5 \%)$ dan membawa implikasi bahwa terdapat hubungan jangka panjang positif antara CAR terhadap NPF segmen Bisnis Banking, dimana apabila CAR mengalami peningkatan satu persen maka akan meningkatkan NPF segmen Bisnis Banking sebesar 1.6528, atau sebaliknya apabila CAR mengalami penurunan sebesar satu persen maka akan menurunkan NPF segmen Bisnis Banking sebesar 1.6528. Capital Adequacy Ratio
(CAR) adalah rasio yang menunjukkan perbandingan antara jumlah modal (baik modal inti maupun modal pelengkap) terhadap Aktiva Tertimbang menurut Resiko (ATMR). CAR merupakan rasio yang digunakan oleh Bank Indonesia sebagai indikator untuk menetapkan ketentuan penyediaan modal minimum bank. Meningkatnya CAR maka semakin tinggi pula modal yang dimiliki bank, sehingga semakin besar pula kemampuan untuk melakukan penyaluran pembiayaan dan resiko terjadinya pembiayaan bermasalah juga akan semakin meningkat. Dengan demikian semakin tinggi CAR, maka semakin tinggi pula pembiayaan bermasalah (NPL).

Nilai t-statistik variabel FDR jangka panjang sebesar -2.8545 dengan probabilitas sebesar 0.0062 dan koefisien jangka panjang sebesar -0.0956. Hal ini mengandung pengertian bahwa variabel FDR berpengaruh signifikan pada tingkat kepercayaan $\alpha(5 \%)$ dan membawa implikasi bahwa terdapat hubungan jangka panjang negatif antara FDR terhadap NPF segmen Bisnis Banking, dimana apabila FDR mengalami peningkatan satu persen maka akan menurunkan NPF segmen Bisnis Banking sebesar -0.0956, atau sebaliknya apabila FDR mengalami penurunan sebesar satu persen maka akan meningkatkan NPF segmen Bisnis Banking sebesar -0.0956. FDR merupakan rasio perbandingan antara total jumlah dana yang disalurkan ke masyarakat (pinjaman) dengan jumlah dana masyarakat dan modal sendiri yang digunakan (Mulyono, 1995). Rasio ini digunakan untuk mengukur likuiditas suatu bank. Rasio yang tinggi menggambarkan bahwa bank menyalurkan seluruh dananya (menyalurkan pinjaman) kepada masyarakat atau relatif tidak likuid (illikuid). Menurut Priatmaja (2011) dalam Akbar (2016) dijelaskan bahwa likuiditas yang baik bagi suatu bank menandakan bahwa bank tersebut memiliki sumber dana yang cukup tersedia 
untuk memenuhi seluruh kewajibannya. Sehingga semakin tinggi likuiditas dari suatu bank maka akan mengurangi resiko terjadinya pembiayaan yang bermasalah. Kondisi ini dapat terlihat pada bank yang menyalurkan pembiayaanya kepada nasabahnya memiliki kualitas yang baik, hal ini menyebabkan ekspansi yang dilakukan akan meningkatkan return bank dan menurunkan tingkat pembiayaan bermasalah (NPF). Hasil ini sama dengan penelitian yang dilakukan oleh Haifa dan Wibowo (2015).

Nilai t-statistik variabel NMR jangka panjang sebesar -2.4137 dengan probabilitas sebesar 0.0193 dan koefisien jangka panjang sebesar -0.4208. Hal ini mengandung pengertian bahwa variabel NMR berpengaruh signifikan pada tingkat kepercayaan $\alpha(5 \%)$ dan membawa implikasi bahwa terdapat hubungan jangka panjang negatif antara NMR terhadap NPF, dimana apabila NMR mengalami peningkatan satu persen maka akan menurunkan NPF sebesar -0.4208 , atau sebaliknya apabila NMR mengalami penurunan sebesar satu persen maka akan meningkatkan NPF segmen Bisnis Banking sebesar -0.4208. Nett Revenue Margin (NRM) adalah rasio yang digunakan untuk mengukur kemampuan manajemen dalam mengelola aktiva produktif guna menghasilkan pendapatan bagi hasil. Pendapatan bagi hasil diperoleh dari selisih antara nisbah bagi hasil porsi bank dengan nisbah bagi hasil porsi nasabah. Semakin besar rasio NRM menunjukkan adanya selisih yang besar antara nisbah bagi hasil yang diperoleh bank dengan nisbah bagi hasil yang diperoleh nasabah, sehingga kemungkinan terjadinya pembiayaan bermasalah semakin kecil.

Nilai t-statistik variabel BI rate jangka panjang sebesar 5.7756 dengan probabilitas sebesar 0.0000 dan koefisien jangka panjang sebesar 2.2750. Hal ini mengandung pengertian bahwa variabel BI rate berpengaruh signifikan pada tingkat kepercayaan $\alpha(5 \%)$ dan membawa implikasi bahwa terdapat hubungan jangka panjang positif antara BI rate terhadap NPF segmen Bisnis Banking, dimana apabila BI rate mengalami peningkatan satu persen maka akan meningkatkan NPF segmen Bisnis Banking sebesar 2.2750, atau sebaliknya apabila BI rate mengalami penurunan sebesar satu persen maka akan menurunkan NPF segmen Bisnis Banking sebesar 2.2750. Meningkatnya BI Rate akan meningkatkan NPF segmen Bisnis Banking bank. Meningkatnya BI rate akan mengakibatkan kenaikan suku bunga pada perbankan, baik suku bunga simpanan maupun pinjaman. Jika bank menaikkan tingkat suku bunga pinjaman maka akan berdampak pada resiko kredit bermasalah yang disebabkan beban bunga yang ditanggung debitur semakin berat. BI rate yang tinggi dapat menyebabkan pada resiko tidak bersaingnya bagi hasil dana pihak ketiga pada bank syariah. Rasio ini dapat juga muncul yang disebabkan naiknya expected competitive return dari nasabah. Untuk mengelola resiko ini bank syariah dapat menetapkan jangka waktu maksimal pada penyaluran pembiayaannya dengan mempertimbangkan hal-hal seperti keuntungan saat ini dan prediksi perubahan di masa mendatang yang berlaku di pasar perbankan syariah. Saat BI rate naik dan mempengaruhi peningkatan suku bunga pinjaman pada bank konvensional, hal ini menguntungkan perbankan syariah karena marginnya semakin bersaing dengan bank konvesnional. Pada saat margin bank syariah semakin kompetitif, maka akan berdampak pada peningkatan penyaluran pembiayaan. Peningkatan pada penyaluran pembiayaan memungkinkan terjadinya pembiayaan bermasalah yang semakin tinggi.Hasil ini sesuai dengan penelitian yang dilakukan oleh Haifa dan Wibowo (2015) serta Ardana dan Irviani (2017) dimana BI rate berpengaruh terhadap NPF. 


\section{KESIMPULAN}

Berdasarkan persamaan diatas, dapat dilihat bahwa dalam jangka pendek yang memiliki pengaruh terhadap NPF segmen Bisnis Banking yaitu variabel BOPO dengan nilai t-statistik sebesar 4.6604 dengan probabilitas sebesar 0.0000 dan koefisien jangka pendek sebesar 0.3721. Sementara variabel CAR, FDR, NMR, BI rate dan Inflasi tidak terdapat hubungan jangka pendek terhadap NPF segmen Bisnis Banking. Dalam jangka panjang, variabel yang berpengaruh terhadap NPF segmen Bisnis Banking meliputi variabel BOPO, CAR, FDR, NMR, dan BI rate. Adapun untuk variabel inflasi dengan nilai t-statistik sebesar 1.1648, probabilitas sebesar 0.2494 dan koefisien jangka panjang sebesar 0.2198, dalam jangka panjang tidak berpengaruh terhadap NPF segmen Bisnis Banking.

\section{REFERENCES}

Akbar, D.A. (2016). Inflasi, Gross Domesctic Product (GDP), Capital Adequacy Ratio (CAR), dan Finance To Deposit Ratio (FDR) Terhadap Non Performing Financing (NPF) Pada Bank Umum Syariah di Indonesia. Jurnal I-Economic. Vol. 2 (2), pp. 19 - 37.

Ardana, Y. \& Irviani, R. (2017). Kondisi Makroekonomi Terhadap Tingkat Pembiayaan Bermasalah Bank Umum Syariah di Indonesia (Periode Januari 2009-Desember 2015 Dengan Model ECM). Jurnal Media Trend. Vol.12 (1) pp. 1-11.

Danupranata, G. (2013). Manajemen Perbankan Syariah. Jakarta: Salemba Empat.

Dendawijaya, L. (2009). Manajemen Perbankan. Jakarta: Ghalia Indonesia.

Divisi Statistik Sektor Riil Bank Indonesia. (2017). Survei Perbankan. Jakarta: Bank Indonesia.

Haifa, \& Wibowo, D. (2015). The Influence
Macroeconomic on Non Performing Financing of Indonesian Islamic Bank In 2010:01 - 2014:04. Jurnal Nisbah. Vol. 1(2), pp. 74-87.

Juanda, B., \& Junaidi. (2012). Ekonometrika Deret Waktu. Bogor: PT Penerbit IPB Press.

Kasmir. (2014). Bank dan Lembaga Keuangan Lainnya. Jakarta: PT Rajagrafindo Persada.

Muhammad, M. (2014). Kointegrasi dan Estimasi ECM Pada Data Time Series. Jurnal Konvergensi. Vol. 4(1), pp. 42-51.

Mulyono, TP. (1995). Analisa Laporan Keuangan Untuk Perbankan. Jakarta: Penerbit dan Percetakan (UPP) AMP YKPN

Riyadi, S. (2004). Banking Asset \& Liabillity Management Edisi ke-2. Jakarta: Lembaga Penerbit Fakultas Ekonomi.

Sutojo, S. (2000). Strategi Manajemen Bank Umum : Konsep, Teknik dan Kasus. Jakarta: Damar Mulia Pustaka.

Widyawati, S. \& Wahyudi, S.T. (2016). Determinan Pertumbuhan Kredit Modal Kerja Perbankan di Indonesia: Pendekatan Error Correction Model (ECM). Jurnal Keuangan dan Perbankan. Vol. 20(1), pp. 149-156. 